\title{
Pelagic deep-sea fauna observed on video transects in the southern Norwegian Sea
}

\author{
Philipp Neitzel ${ }^{1} \cdot$ Aino Hosia $^{2} \cdot$ Uwe Piatkowski $^{1} \cdot$ Henk-Jan Hoving ${ }^{1}$ (])
}

Received: 15 June 2020 / Revised: 24 February 2021 / Accepted: 2 March 2021 / Published online: 22 March 2021

(c) The Author(s) 2021

\begin{abstract}
Observations of the diversity, distribution and abundance of pelagic fauna are absent for many ocean regions in the Atlantic, but baseline data are required to detect changes in communities as a result of climate change. Gelatinous fauna are increasingly recognized as vital players in oceanic food webs, but sampling these delicate organisms in nets is challenging. Underwater (in situ) observations have provided unprecedented insights into mesopelagic communities in particular for abundance and distribution of gelatinous fauna. In September 2018, we performed horizontal video transects (50-1200 m) using the pelagic in situ observation system during a research cruise in the southern Norwegian Sea. Annotation of the video recordings resulted in 12 abundant and 7 rare taxa. Chaetognaths, the trachymedusa Aglantha digitale and appendicularians were the three most abundant taxa. The high numbers of fishes and crustaceans in the upper $100 \mathrm{~m}$ was likely the result of vertical migration. Gelatinous zooplankton included ctenophores (lobate ctenophores, Beroe spp., Euplokamis sp., and an undescribed cydippid) as well as calycophoran and physonect siphonophores. We discuss the distributions of these fauna, some of which represent the first record for the Norwegian Sea.
\end{abstract}

Keywords Norwegian Sea $\cdot$ Zooplankton $\cdot$ Micronekton $\cdot$ Macroplankton $\cdot$ In situ observations $\cdot$ Vertical migration Aglantha

\section{Introduction}

The pelagic ocean is the largest habitat on the planet and houses a high diversity, abundance and biomass of organisms. Up to $25 \%$ of the pelagic biomass can consist of gelatinous zooplankton (Robison 2004). Gelatinous organisms mainly consisting of the pelagic Cnidaria, Ctenophora and Tunicata have a variety of different body morphologies and feeding strategies, allowing them to occupy different niches in the oceanic foodweb (Haddock 2004). Pelagic tunicates (thaliaceans and appendicularians) are filter feeders (Holland 2016), while medusae, siphonophores and ctenophores are predators feeding on a wide spectrum of zooplankton including gelatinous organisms and micronekton (Pagès et al.

Henk-Jan Hoving

hhoving@geomar.de

1 GEOMAR, Helmholtz Centre for Ocean Research Kiel, Düsternbrooker Weg 20, 24105 Kiel, Germany

2 Department of Natural History, University Museum of Bergen, University of Bergen, P.O. Box 7800, 5020 Bergen, Norway
2006). Another prominent and widely distributed phylum in the oceanic water column are Chaetognatha, semi-gelatinous predators that can be among the numerically dominant plankton members of ocean communities (Bone et al. 1991).

Despite their low protein content, gelatinous zooplankton are common prey of many marine taxa including fishes, crustaceans, turtles and even some cephalopods (Heeger et al. 1992; Cardona et al. 2012; Hoving and Haddock 2017). The complex trophic interconnections of gelatinous zooplankton in the pelagic foodweb mark their central role within the pelagic ecosystem and their potential importance in the biological carbon pump (Alldredge 2004; Lebrato et al. 2012; Henschke et al. 2013; Sweetman and Chapman 2015). Gelatinous organisms have several traits that may give them an advantage in warmer, deoxygenated waters (Thuesen et al. 2005; Ekau et al. 2010). Although blooms of gelatinous organisms have been occurring for millennia, recent observations have drawn scientific and public interest to the question of whether or not the frequency of such blooming events is increasing, e.g. as a result of climate change (Lynam et al. 2011; Brotz et al. 2012; Condon et al. 2012, 2013). Confirming such potential increases requires a 
baseline of species diversity, distribution and abundance of gelatinous organisms.

Fragile gelatinous zooplankton is often damaged or destroyed when sampled with nets, which has led to a systematic underestimation of its abundance and diversity in the ocean, in particular in the deep pelagic. The use of in situ observations (with optical sampling systems) has changed our perspective substantially (Haddock 2004; Robison 2004). Manned submersibles and remotely operated vehicles (ROVs) allow the observation of fragile gelatinous zooplankton in their natural habitat. Midwater ocean exploration with these vehicles has led to the discovery of new gelatinous species and records (e.g. Matsumoto and Robison 1992; Hoving et al. 2018), the documentation of their behaviour (Robison et al. 2017) and the provision of novel information on the trophic interactions in the deepsea 'jelly web' (Robison 2004; Choy et al. 2017; Hoving and Haddock 2017). Although submersibles and ROVs can provide detailed images and video material of large deep pelagic fauna and allow faunal collections (Robison 2004), they are also challenging and costly to operate. To allow cost-effective pelagic video transects comparable to ROV video transects, the pelagic in situ observation system (PELAGIOS) was developed (Hoving et al. 2019). The PELAGIOS is a camera platform that collects concomitant environmental data while towed horizontally at desired depths. The annotation of the high definition video results in diversity, distribution and abundance data of slow-swimming pelagic fauna larger than $1 \mathrm{~cm}$. To establish a baseline of pelagic fauna distribution and abundance, and to identify potential important contributors (e.g. medusae, squids, larvaceans) to the biological carbon pump, we performed deep-sea pelagic video transects with PELAGIOS in the southern Norwegian Sea.

\section{Material and methods}

During a research cruise on R/V Heincke in September 2018 in the southern Norwegian Sea, we deployed the pelagic in situ observation system (PELAGIOS) four times to perform horizontal pelagic video transects (Fig. 1; Table 1). The PELAGIOS is a battery powered towed camera platform with a high definition camera (type 1Cam Alpha, SubC Imaging), forward LED illumination, a CTD (SBE 19 SeaCAT, Sea-Bird Scientific) and a telemetry (DST-6, Sea and Sun Technology; Linke et al. 2015) that transmits data and video preview via the CTD conducting cable to the deck unit (Hoving et al. 2019). The PELAGIOS was towed over the side of the ship on the CTD conducting cable at approximately $1 \mathrm{knot}(0.51 \mathrm{~m} / \mathrm{s})$ speed over ground. The desired towing depth for the pelagic video transect was reached by paying out CTD wire while monitoring the depth from the CTD. The duration of one complete PELAGIOS deployment was between $3 \mathrm{~h} 11 \mathrm{~min}$ and $3 \mathrm{~h} 28 \mathrm{~min}$, and at each depth we towed for approximately 6.5-23.3 $\mathrm{min}$ (Tables 1 and 2). Horizontal video transects were performed at specific depths between 50 and $1200 \mathrm{~m}$ (Table 2) and from 16:00 to 20:00 UTC (Table 1). We started with the deepest transect and ended shallow on Station_1. At all other stations we started shallow and ended with the deepest transect (Table 2). Hydrography of the water column was reconstructed by performing a vertical cast with an onboard SBE CTD (Fig. 2).
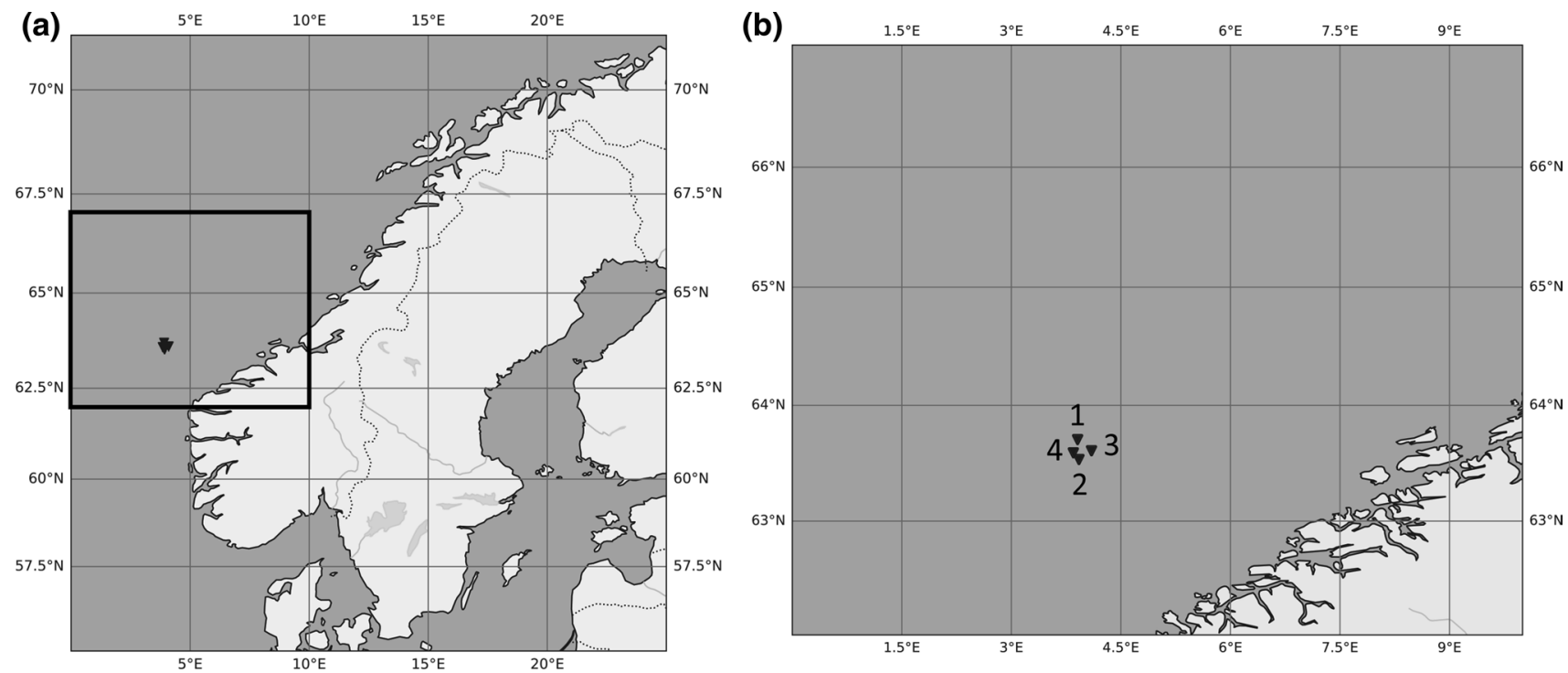

Fig. 1 a The study area in the Norwegian Sea and $\mathbf{b}$ the four locations where PELAGIOS deployments were performed during HE518 indicated by black triangles 
Table 1 Stations with PELAGIOS deployments during the cruise HE518 in September 2018

\begin{tabular}{lllllll}
\hline Station & Date & Latitude (N) & Longitude (E) & Start (UTC) & Stop (UTC) & $\begin{array}{l}\text { Sunset } \\
\text { (UTC+Daylight } \\
\text { Saving Time) }\end{array}$ \\
\hline $\begin{array}{l}\text { Sation_1 } \\
\text { HE518_5-1 }\end{array}$ & $2018-09-09$ & 63.7059 & 3.90709 & $16: 07: 00$ & $19: 46: 00$ & $19: 31: 00$ \\
$\begin{array}{l}\text { Station_2 } \\
\text { HE518_11-1 }\end{array}$ & $2018-09-10$ & 63.5343 & 3.92559 & $16: 28: 00$ & $19: 50: 00$ & $19: 31: 00$ \\
$\begin{array}{l}\text { Station_3 } \\
\text { HE518_17_1 }\end{array}$ & $2018-09-11$ & 63.6097 & 4.09736 & $16: 37: 00$ & $19: 55: 00$ & $19: 23: 00$ \\
$\begin{array}{l}\text { Station_4 } \\
\text { HE518_28-1 }\end{array}$ & $2018-09-14$ & 63.59188 & 3.84858 & $16: 19: 00$ & $19: 30: 00$ & $19: 14: 00$ \\
\hline
\end{tabular}

The HE518_number refers to the cruise station list
Table 2 Overview of the transect depths targeted at each station by PELAGIOS

\begin{tabular}{lllll}
\hline Depth $[\mathrm{m}]$ & \multicolumn{4}{l}{ Transect length [min:sec] } \\
\cline { 2 - 5 } & Station_1 & Station_2 & Station_3 & Station_4 \\
\hline 50 & $11: 20$ & $15: 47$ & $/$ & $/$ \\
75 & $9: 43$ & $/$ & $/$ & $/$ \\
100 & $/$ & $11: 54$ & $10: 35$ & $/$ \\
200 & $/$ & $12: 44$ & $13: 49$ & $11: 39$ \\
300 & $/$ & $12: 52$ & $9: 41$ & $10: 01$ \\
400 & $/$ & $13: 19$ & $16: 20$ & $10: 24$ \\
500 & $6: 35$ & $10: 47$ & $17: 05$ & $10: 31$ \\
600 & $7: 46$ & $19: 27$ & $14: 44$ & $20: 29$ \\
700 & $20: 34$ & $18: 25$ & $18: 00$ & $20: 17$ \\
800 & $20: 10$ & $17: 52$ & $15: 02$ & $20: 10$ \\
850 & $/$ & $/$ & $/$ & $14: 29$ \\
900 & $16: 59$ & $/$ & $15: 12$ & $6: 51$ \\
1000 & $15: 23$ & $/$ & $/$ & $23: 20$ \\
1100 & $18: 42$ & $/$ & $/$ & $/$ \\
1200 & $17: 59$ & $/$ & $/$ & $/$ \\
\hline
\end{tabular}

The ' $\%$ marks absence of a pelagic video transect

The HD video was annotated using the Video Annotation and Reference System (VARS) developed by the Monterey Bay Aquarium Research Institute (MBARI) (Schlining and Jacobsen Stout 2006). Recorded organisms larger than $1 \mathrm{~cm}$ in diameter were annotated and identified to the lowest possible taxonomic classification. Organisms observed while PELAGIOS was ascending or descending between transects were annotated but not considered in our data analysis. After the analysis of the video material the observation data were matched with the depth data and classified with the corresponding transects. This resulted in 15 abundant taxa (Table 3) and additional rare taxa, as well as groupings of unidentifiable organisms due to poor image conditions (Table 4).

To calculate abundances, we divided the absolute number of counts of each taxon per transect by the

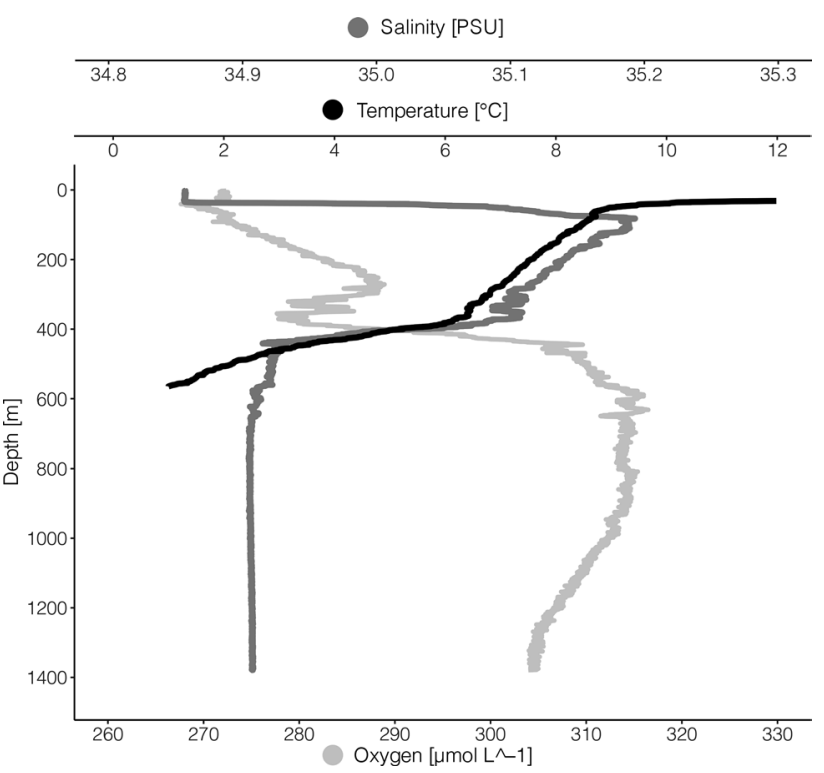

Fig. 2 Vertical profiles of temperature, salinity, dissolved oxygen and density from the surface to $1350 \mathrm{~m}$ depth. The CTD-cast was performed at the 15th of September 2018 at 06:58 UTC at $63^{\circ} 35^{\prime} 24 \mathrm{~N}$ and $3^{\circ} 57^{\prime} 26 \mathrm{E}$. Temperature data below $580 \mathrm{~m}$ was not available

corresponding transect duration to obtain the relative abundance of taxa in individuals per time unit. To calculate the number of individuals per unit volume, we used faunal observations from simultaneous deployments of the PELAGIOS and a Underwater Vision Profiler (UVP5) together (Hoving et al. 2019). The UVP5 samples a fixed volume enabling a back calculation of the sampled volume of PELAGIOS during the same transect. This resulted in a conversion factor of 6 . This factor is based on pelagic worms of the genus Poeobius $(0.8-1.5 \mathrm{~cm})$, which are poor swimmers and were observed clearly by both UVP5 and PELAGIOS (Christiansen et al. 2018; Hoving et al. 2019). The conversion factor may change when considering larger animals that can be seen from further away (Reisenbichler 
Table 3 Weighted mean depth (m) of the 12 most abundant taxa and 3 rare taxa (Beroe, Bolinopsis and white Cydippida) encountered by PELAGIOS, at each station and the overall weighted mean with standard deviation $(\mathrm{SD})$

\begin{tabular}{|c|c|c|c|c|c|c|}
\hline \multirow[t]{2}{*}{ Observation } & \multicolumn{4}{|l|}{ Station } & \multirow[t]{2}{*}{ Mean } & \multirow[t]{2}{*}{$\pm \mathrm{SD}$} \\
\hline & 1 & 2 & 3 & 4 & & \\
\hline Actinopteri & 80.9 & 122.5 & 239.4 & 320 & 190.7 & \pm 94.6 \\
\hline Euphausiacea & 112.7 & 290.5 & 509.1 & 597.2 & 377.4 & \pm 189.3 \\
\hline Decapoda \& Mysida & 989.2 & 665.9 & 797.7 & 840.8 & 823.4 & \pm 115.4 \\
\hline Chaetognatha & 757 & 555.4 & 668.8 & 689.3 & 667.6 & \pm 72.6 \\
\hline Appendicularia & 896.5 & 657.5 & 643.7 & 800 & 749.4 & \pm 104.6 \\
\hline Clione & 69.8 & 50 & Absent & 600 & 239.9 & \pm 254.7 \\
\hline Aglantha & 765.9 & 582.6 & 754.9 & 770.5 & 718.5 & \pm 78.6 \\
\hline Diphyidae & 75 & 99.9 & 108.7 & 200 & 120.9 & \pm 47.3 \\
\hline Other Calycophorae & 598.2 & 391.8 & 516.2 & 496.6 & 500.7 & \pm 73.5 \\
\hline Physonect Deep-type & 1036.4 & 777.5 & 900 & 908.1 & 905.5 & \pm 91.6 \\
\hline Other Physonectae & 90.8 & 241.4 & 284.1 & 337 & 238.3 & \pm 91.7 \\
\hline Beroe & 913 & 406.1 & 603.3 & 600 & 630.6 & \pm 181.5 \\
\hline Bolinopsis & 800 & 412.3 & 610 & 650.2 & 618.1 & \pm 138.3 \\
\hline Euplokamis & 187.2 & 360.4 & 448.6 & 485.6 & 370.5 & \pm 115.1 \\
\hline White Cydippida & 1120.1 & 750.8 & 645 & 1000 & 879 & \pm 189.7 \\
\hline
\end{tabular}

Table 4 Pooled counts per transect depths of the rare taxa Cirrata, Polychaeta, Pyrosomatida and Salpida

\begin{tabular}{|c|c|c|c|c|c|c|c|c|c|c|c|c|c|c|c|}
\hline \multirow[t]{2}{*}{ Observation } & \multicolumn{15}{|c|}{ Transect depth (m) } \\
\hline & 50 & 75 & 100 & 200 & 300 & 400 & 500 & 600 & 700 & 800 & 850 & 900 & 1000 & 1100 & 1200 \\
\hline Beroe & & & & & 1 & 2 & 1 & 2 & 2 & 1 & & 1 & & & 1 \\
\hline Bolinopsis & & & & 1 & 2 & 2 & & 7 & 2 & 2 & & 1 & & & \\
\hline Cirrata & & & & & & & & & 1 & & $1 *$ & & & & \\
\hline Polychaeta & & & & & 1 & & & & 2 & & & & & & \\
\hline Pyrosoma & & & & & & & & & & & & 1 & & & \\
\hline Salpida & 5 & & & & & & & & & & & & & & \\
\hline Unident Cydippida & & & & & & 3 & 7 & & 3 & 1 & & & 1 & & \\
\hline Unident Ctenophora & & & & & & & & 1 & & & & & & & \\
\hline Unident Hydromedusae & & & & & 1 & 1 & 1 & & 1 & 1 & & 5 & 2 & 1 & 1 \\
\hline Unident Lobata & & 1 & & & & & 1 & 2 & 1 & & 1 & & 1 & & \\
\hline Unident Pteropoda & 1 & & & 3 & & & & & & & & & & & \\
\hline Unident Siphonophora & 1 & & & & 1 & 2 & & & 2 & & & & & & \\
\hline Unidentified organism & & & & & & & & & 1 & 2 & 1 & 7 & 5 & 6 & 2 \\
\hline White Cydippida & & & & & & & & 1 & 2 & 1 & & & 4 & 1 & 2 \\
\hline
\end{tabular}

Unidentified Hydromedusae other than Aglantha digitale, as well as Ctenophora and Siphonophora not identifiable to a lower taxon

$1 *$ The observation of this cirrate octopod was not made during a transect, but during a descend phase in between a 800 and a $900 \mathrm{~m}$ transect

et al. 2016) or due to the consistency and transparency of the organisms affecting their visibility.

All graphs besides the map were produced in $\mathrm{R}$ version 3.6.1. The map was made with python and the packages matplotlib and cartopy.

Differences between stations were analyzed by calculating the weighted mean depth for each station as well as an overall weighted mean for each of the 15 most abundant taxa (Latasa et al. 2017).

\section{Results}

\section{Hydrography}

The hydrography was typical for the studied region (Blindheim and Rey 2004). The upper $<50 \mathrm{~m}$ were influenced by the Norwegian Coastal Current (NCC), with a salinity well below 34.9 and temperatures $>12{ }^{\circ} \mathrm{C}$ (Fig. 2). Below 
the NCC, the salinity increased to $>35$, indicating a layer of Atlantic Water (AW) extending down to $400 \mathrm{~m}$. At around $400 \mathrm{~m}$, the salinity rapidly dropped to $\sim 34.92$ with a minor salinity minimum close to $450 \mathrm{~m}$, and there was a simultaneous increase in oxygen concentration moving from AW to intermediate water. Temperature steadily declined from 5 to $0{ }^{\circ} \mathrm{C}$ between $\sim 400$ and $600 \mathrm{~m}$. We expect that below the intermediate water masses and deeper than $\sim 600 \mathrm{~m}$ Norwegian Sea Deep Water (NSDW) was found. This water mass is characterized by temperatures below $0{ }^{\circ} \mathrm{C}$ and a salinity of $\sim 34.91$. Unfortunately, temperature data below $580 \mathrm{~m}$ were corrupted.

\section{Fauna}

The video transects revealed 26 different taxa; fifteen abundant taxa (Table 3) and seven rare and seven unidentified taxa (Table 4). At all four sampling sites, the transects at 500, 600, 700 and $800 \mathrm{~m}$ depth had the highest animal abundances. Chaetognatha, which showed their highest abundances in these depths, dominated all transects with $68.8,67.0,63.0$, and $64.6 \%$ of all annotations (Station_1 to Station_4, respectively) (Fig. 3). The small trachymedusa Aglantha digitale had its distribution peak between 500 and $800 \mathrm{~m}$ (Figs. 3 and 4) and accounted for 25.2, 22.4, 27.6 and $24.7 \%$ of all annotations (Station_1 to Station_4, respectively) and was the second most abundant taxon encountered in all transects. Appendicularians, crustaceans, ctenophores and siphonophores combined contributed about $10 \%$ of the observations between 500 and $800 \mathrm{~m}$ at Stations 2, 3 and 4, and less than $6 \%$ of the observations at Station_1.

The 12 most abundant taxa differed in their vertical distribution patterns (Fig. 3). Non-gelatinous taxonomic groups included Actinopteri (ray-finned fishes), Decapoda and Mysida (jointly called shrimps, because distinction between the taxa was not possible on the videos), Euphausiacea (krill) and the semi-gelatinous Chaetognatha (arrow worms). Highest Actinopteri abundances were observed in the upper $100 \mathrm{~m}$ with a maximum of 267.6 ind $1000 \mathrm{~m}^{-3}$ at $75 \mathrm{~m}$ at Station_1, and abundances decreased with depth. Shrimps were observed at all stations and throughout the entire sampling depth range, but increased in numbers below $700 \mathrm{~m}$, with a maximum of 76 ind $1000 \mathrm{~m}^{-3}$ at the single transect at $850 \mathrm{~m}$ depth at Station_4. A secondary abundance peak was observed at the deepest transect of $1200 \mathrm{~m}$ with 50.1 ind $1000 \mathrm{~m}^{-3}$ at Station_1. Euphausiacea were also observed at all stations and at every sampled depth, except at $1200 \mathrm{~m}$. Their highest abundances were observed at $50 \mathrm{~m}$ depth at Station_1 with 5461.8 ind $1000 \mathrm{~m}^{-3}$. Below $100 \mathrm{~m}$, the abundance of Euphausiacea decreased by approximately one order of magnitude, and below $800 \mathrm{~m}$ depth by another order of magnitude.
Appendicularians were present throughout the sampled depth range with the exception of the $75 \mathrm{~m}$ transect at Station_1. Their numbers showed a continuous increase with depth, and peaked at $1000 \mathrm{~m}$ depth with 339.8 ind $1000 \mathrm{~m}^{-3}$ (mean, $\mathrm{sd}=98.7$ ). Chaetognaths were dominant between 200 and $1000 \mathrm{~m}$. They were observed throughout the whole depth range (Fig. 3), and their vertical distribution pattern showed a normal distribution around an abundance peak at $700 \mathrm{~m}$ depth with 3350.5 ind $1000 \mathrm{~m}^{-3}$ (mean, $\mathrm{sd}=1063.3$ ). The highest numbers of pteropods of the genus Clione $\left(157.6\right.$ ind $1000 \mathrm{~m}^{-3}$ ; mean, sd $=213.9$ ) occurred at $50 \mathrm{~m}$ depth, but these mollusks were also present at 600 and $700 \mathrm{~m}$. The trachymedusa Aglantha digitale was present between 50 and $1000 \mathrm{~m}$ depth but absent from the 75, 100 and $200 \mathrm{~m}$ transects (Figs. 3 and 4). Their highest abundance was observed at $800 \mathrm{~m}$ depth with 1507 ind $1000 \mathrm{~m}^{-3}$ (mean, sd =963.5), and below $850 \mathrm{~m}$ depth the abundance decreased sharply. After chaetognaths, A. digitale was the second most abundant taxon. Small, unidentified calycophoran siphonophores were grouped together as 'other Calycophorae' and occurred between 300 and $1200 \mathrm{~m}$ depth. They were more abundant in the upper half of their distributional range and their peak abundance was 100.5 ind $1000 \mathrm{~m}^{-3}$ (mean, $\mathrm{sd}=81.1$ ) at $500 \mathrm{~m}$ depth. Calycophoran siphonophores of the family Diphyidae were restricted in their vertical distribution to the upper $200 \mathrm{~m}$. They had their highest abundance at $100 \mathrm{~m}$ depth with 88.2 ind $1000 \mathrm{~m}^{-3}$ (mean, $\mathrm{sd}=17.9$ ). A group of physonect siphonophores with a similar morphology, but which could not be identified to species, were grouped as 'Physonect Deep-type' (Fig. 3). These siphonophores occurred from 400 to $1200 \mathrm{~m}$ depth, but the majority of specimens were observed at $1100 \mathrm{~m}$ depth with 107 ind $1000 \mathrm{~m}^{-3}$ at Station_1. Physonect siphonophores other than the 'Physonect Deep-type' were observed from 50 to $800 \mathrm{~m}$ as well as at $1000 \mathrm{~m}$. Their abundance decreased with depth after a peak at $75 \mathrm{~m}$ (102.9 ind $1000 \mathrm{~m}^{-3}$ ) at Station_1. Beroe spp. ctenophores were observed in low numbers from 300 to $1200 \mathrm{~m}$ depth. The maximum abundance was 6.6 ind $1000 \mathrm{~m}^{-3}$ (mean, $\mathrm{sd}=6.2$ ) at $400 \mathrm{~m}$ depth. Some of the observed Beroe spp. could be clearly identified as $B$. abyssicola based on the conspicuous red coloration of the stomodaeum (Fig. 4). The habitus of the others points towards the unresolved species complex Beroe cf. cucumis (Bayha et al. 2004; Mills and Haddock 2007; Johansson et al. 2018), suggesting the presence of at least two species of Beroe in the study area. The lobate ctenophore Bolinopsis (Bolinopsis sp. or Bolinopsis infundibulum) was observed from 200 to $900 \mathrm{~m}$ depth. The maximum abundance of Bolinopsis was at $600 \mathrm{~m}$ with 10.1 ind $1000 \mathrm{~m}^{-3}$ (mean, $\mathrm{sd}=8.3$ ). The cydippid ctenophore Euplokamis sp. was observed 

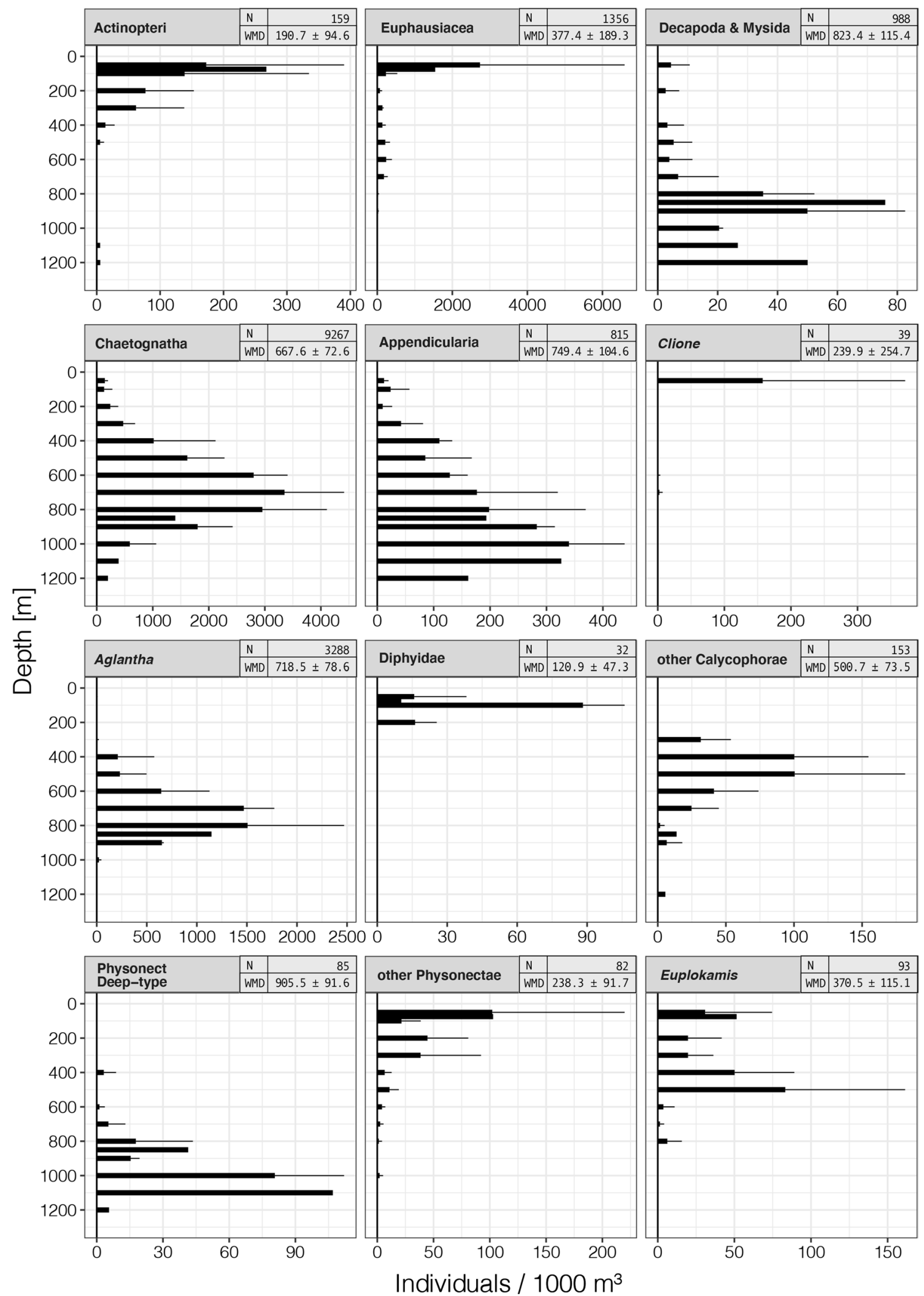

Fig. 3 Vertical distribution profiles of the 15 observed major taxa, with the extrapolated number of specimens per $1000 \mathrm{~m}^{3}$ on the horizontal axes and the water depth on the vertical axes. Columns show the mean abundances across all 4 sampling sites, with the standard deviation (sd) as error bars. The header of the single plots gives the taxon, the weighted mean depth (WMD) and the total number of counts for each taxon $(\mathrm{N})$. The shallowest transect was conducted at $50 \mathrm{~m}$ depth, the deepest at $1200 \mathrm{~m}$ depth 
Fig. 4 Frame-grabs of Norwegian pelagic fauna from videos recorded with PELAGIOS.

From top left to bottom right the rows show the following taxa: a Beroe abyssicola. $\sim 40 \mathrm{~mm}$ (Johansson et al. 2018); b lobate ctenophore Bolinopsis sp. $40 \mathrm{~mm}$ (Nagabhushanam 1959); c cydippid ctenophore Euplokamis sp. $\sim 10 \mathrm{~mm}$ (Granhag et al. 2012); d undescribed white cydippid; e Aglantha digitale $\sim 10 \mathrm{~mm}$ (Hosia and Båmstedt 2007); f Physonect siphonophore; g Physonect Deep-type; $\mathbf{h}$ Appendicularian; i Chaetognatha $40 \mathrm{~mm}$ (Falkenhaug 1991); j Clione sp. $20 \mathrm{~mm}$ (Satterlie et al. 1985); $\mathbf{k}$ cirrate octopod

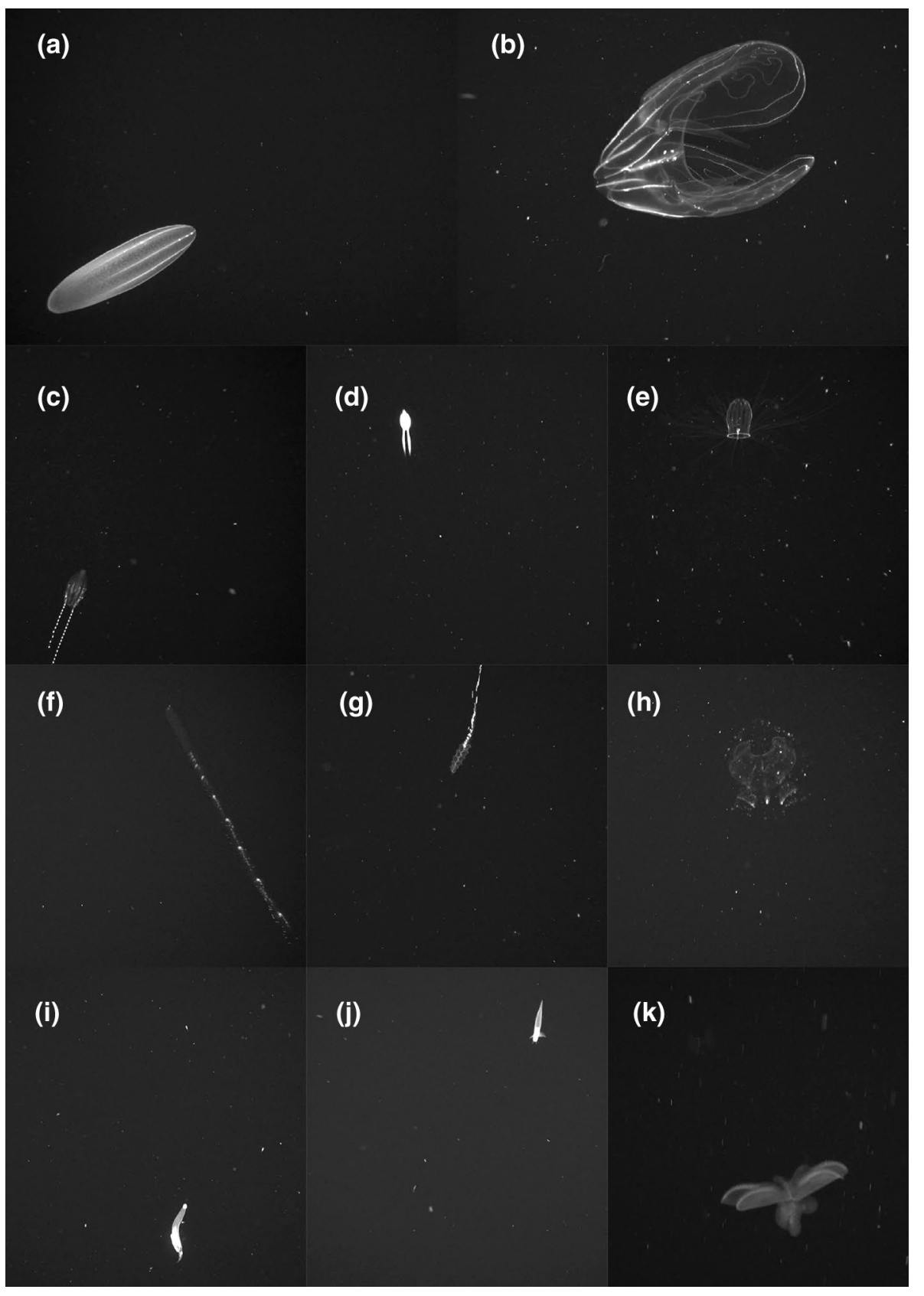

at 50, 75 and from 200 to $800 \mathrm{~m}$ depth (Figs. 3 and 4). Their maximum abundance was 83.2 ind $1000 \mathrm{~m}^{-3}$ (mean, $\mathrm{sd}=78.2$ ) at $500 \mathrm{~m}$ depth. An undescribed white cydippid (Hosia and Båmstedt 2007) was observed from 600 to $800 \mathrm{~m}$ and from 1000 to $1200 \mathrm{~m}$ depth (Figs. 3 and 4). Their highest abundance of 11.1 ind $1000 \mathrm{~m}^{-3}$ was observed during the deepest transect at $1200 \mathrm{~m}$ depth.

Fourteen groups of organisms were observed in low numbers, including unidentifiable ctenophores, siphonophores, and hydromedusae, pelagic tunicates, polychaetes and cirrate octopods (Fig. 4; Table 4).

\section{Discussion}

Our observations included 12 abundant, seven rare, and seven unidentified pelagic taxa. The numerically dominant group were chaetognaths, followed by the small trachymedusa Aglantha digitale, both predators on other zooplankton. Filter feeding appendicularians were the third most abundant group. Crustaceans, which we divided into krill (Euphausiacea) and shrimps (Decapoda and Mysida), occurred at high densities at specific depth 
layers. Omnivorous krill were the dominant organisms in the uppermost 50, 75 and $100 \mathrm{~m}$ transects, whereas larger shrimps were most abundant much deeper, between 800 and $900 \mathrm{~m}$ depth.

The major faunal components consisting of ray-finned fishes, euphausiids, shrimps, hydrozoans, ctenophores, chaetognaths and appendicularians, as well as the overall pelagic diversity and abundance, are in line with previous observations in the North Atlantic, where optical sampling was performed using ROV and UVP (Vinogradov 2005; Stemmann et al. 2008).

Our in situ video observations are generally limited to organisms that are $>\sim 1 \mathrm{~cm}$ in size, and often do not show sufficient taxonomic characteristics required for identification to species level. Pelagic net surveys provide a higher taxonomic resolution for crustaceans and ray-finned fishes (Piatkowski et al. 1994), as well as for the hydrozoan gelatinous fauna (Hosia et al. 2008, 2017), but catch efficiency may be low. On the other hand, optical sampling like performed in our study does reveal fauna poorly sampled by nets, ctenophores and appendicularians in particular, and provides unique data on the detailed vertical and horizontal distribution of fragile organisms (Hosia et al. 2017). The diversity of gelatinous fauna in the Norwegian Sea remains poorly studied, and more detailed faunistic studies would probably reveal new records of hydrozoans and ctenophores for Norwegian waters. In this study, significant numbers of the cydippid ctenophore Euplokamis sp. $(n=93)$ were documented for the first time in the southern Norwegian Sea. These ctenophores were readily identified to genus due to the characteristically coiled tentilla, resembling droplets along the tentacles (Fig. 2). There are few published records of Euplokamis sp. from Norwegian waters, but it is reported to occur in western Norwegian fjords (Granhag et al. 2012), and has been observed in the Norwegian/Icelandic Sea (Licandro et al. 2015), and near Svalbard (Majaneva and Majaneva 2013). First records of Euplokamis sp. in Swedish waters were reported for the Gullmar Fjord on the west coast (Granhag et al. 2012). Euplokamis may thus be present throughout the Norwegian shelf from the Skagerrak to Svalbard.

The other, yet undescribed, white cydippid ctenophore, similar to an undescribed horned cydippid with highly extensile tentacles (Hosia and Båmstedt 2007), was only observed below $600 \mathrm{~m}$ depth, with highest densities at the $1200 \mathrm{~m}$ transect at Station_1. This suggests that the vertical distribution was not completely sampled, and that the undescribed cydippid is a lower meso- and bathypelagic species with a distribution extending below our sampling range.

Several taxa appeared to be associated with specific water masses. Shrimps were primarily found in NSDW below $600 \mathrm{~m}$. The undescribed white cydippid and the siphonophore that we referred to as the 'Physonect Deep-type' also appeared mostly restricted to these deeper waters. Of the numerically dominant groups, both chaetognaths and Aglantha digitale had their peak abundances below $600 \mathrm{~m}$ depth, in the NSDW. A. digitale was virtually absent from AW, while chaetognaths also extended their distribution to the upper $400 \mathrm{~m}$, perhaps due to this taxon including several species of varying affinity to the different water masses. Euphausiacea, Clione and diphyid siphonophores were primarily observed in the upper AW. Other calycophorans and Euplokamis sp. were particularly abundant in the intermediate waters, but also occurred, to a lesser extent, in the water masses above and below.

Appendicularians were a common group, increasing in abundance with depth throughout the mesopelagic zone. Abundant appendicularians in mesopelagic waters are also reported from other oceanic regions, but are relatively poorly studied (Stemmann et al. 2008). The role of appendicularians in mesopelagic food webs and in vertical flux is nevertheless of high interest. Not only are appendicularians able to feed on particles down to bacterial size range, thus short circuiting the "normal" pelagic food chain (Robinson et al. 2010), but their discarded houses are a major contributor of marine snow particles and vertical flux of carbon (Robison et al. 2005; De La Rocha and Passow 2007).

For some of the observed taxa, potential diel vertical migration (DVM) must also be considered. While relatively detailed, our vertical distribution data only provide a temporal snapshot. Ray-finned fishes, krill, shrimps and physonect siphonophores are known daily vertical migrators (Barham 1966; Piatkowski et al. 1994; Frank and Widder 2002), and their observed distributions in the upper layers may have been indicative of these taxa migrating towards the surface as sunset was approaching. While our data do not provide information on diel changes in the vertical distribution of the observed taxa, deployments were more or less consistent in their timing with respect to the sunset and, thus, the expected stage of DVM. As DVM of many taxa is likely controlled by the ambient light environment (e.g. Norheim et al. 2016), between-day variation may nevertheless have be caused by differences in cloud cover. However, the significant differences found in the distribution of ray-finned fishes were likely caused by the fact that we started the transects in deep waters during the first station, while we started the later stations in shallow waters.

When considering the observed depth distributions and extrapolated abundances, the total number of observations should be taken into account. These data are much more uncertain for the less frequent taxa. Also, the deepest layers at $1000 \mathrm{~m}$ or below only had 1-2 transects per depth, preventing comparisons between sites and general conclusions. Due to the relatively coarse taxonomic resolution of the data, many of the taxa are also likely to contain several species, with potentially different environmental preferences, 
ecological niches and behaviour. For example, three species of krill are common and abundant in the Norwegian Sea: Meganyctiphanes norvegica, Thysanoessa inermis and Thysanoessa longicaudata (Melle et al. 2004). In our data, these and other similar organisms were lumped.

Comparing abundance estimates obtained by different studies is challenging, as they may be affected by a variety of factors including e.g. the sampling methods, interannual and geographical variation, as well as diurnal and/or seasonal changes in abundance and distribution of the target taxa. With these caveats in mind, we can make some comparisons to published data for our most abundant groups. Vertical distributions of chaetognaths in the Norwegian and Greenland Seas have been studied in November 1995 using a Multinet, a multiple plankton net (Dale et al. 1999). The results are surprisingly similar to ours, with maximum densities of 3-4 chaetognaths $\mathrm{m}^{-3}$ observed between 400 and $800 \mathrm{~m}$ depth. For Aglantha digitale, ROV vertical profilesa method comparable to ours in that it is limited to observing organisms larger than $1 \mathrm{~cm}$ in size-from Norwegian fjords in October and May 2004-2005 show peaks of up to $\sim 3$ adult individuals $\mathrm{m}^{-3}$ at around $300 \mathrm{~m}$ depth (Hosia and Båmstedt 2007). These results are also of the same order of magnitude as ours, although the exact depth of the peak abundance differs, perhaps due to local hydrography. The abundance estimates of chaetognaths and $A$. digitale may be realistic because the size of these organisms is similar to the Poeobius polychaete that was used for estimating sampling volume of PELAGIOS (Hoving et al. 2019). Estimating abundance of larger fauna requires further calibration efforts of PELAGIOS as larger fauna may be detected when they are further away from the camera compared to smaller organisms (Reisenbichler et al. 2016).

Our results may to a degree be influenced by attraction or avoidance responses elicited by the PELAGIOS. Such responses could result from the hydrodynamic disturbance caused by the gear, as well as the light. It is known that certain taxa such as ray-finned fishes, krill and decapods, respond to underwater instruments (Stoner et al. 2008). Underestimation of observations may influence our estimates of myctophid and other mesopelagic fishes as they are known to avoid lights and trawls (Kaartvedt et al. 2012). On the other hand, overestimation of abundance may be caused by organisms being attracted towards lights or the instrument itself, as has been reported for other organisms including krill and some ray-finned fishes (e.g. Wiebe et al. 2004; Raymond and Widder 2007; Utne-Palm et al. 2018). However, we did not observe highly reactive responses to the lights.

We have noticed the absence of larger nekton. This particularly is relevant to the oegopsid squid Gonatus fabricii, which is widely distributed in the North Atlantic and adjacent Arctic seas and is the dominant cephalopod in terms of biomass, and a pivotal component in the food web (Kristensen 1984; Wiborg et al. 1984). Gonatus fabricii is consumed by a variety of apex predators such as various cetaceans and deep-sea fishes (Lick and Piatkowski 1998; Santos et al. 1999; Bergstad et al. 2010). It is estimated that sperm whale populations in the north east Atlantic alone consume as much as 1.5 million tons of G. fabricii each year (Bjørke 2001). Our sampling site was chosen because previous studies reported mature and spent females of G. fabricii in the area (Arkhipkin and Bjørke 1999; Bjørke 2001). The absence of G. fabricii could be caused by an avoidance of PELAGIOS resulting in an escape response before specimens are within the view-field of the camera. It is also possible that the sampling volume of the PELAGIOS system and the transects were not sufficient to document the species. However, it should be noted that Gonatus steenstrupi was recorded by ROVs during dives at the northern mid-Atlantic ridge (Vecchione et al. 2010). We furthermore did not observe the coronate medusa Periphylla periphylla, which occurs at high densities in several Norwegian fjord systems (e.g. Båmstedt et al. 2003), and which is also common in the Norwegian Sea in depths below 200 m (Dalpadado et al. 1998). The absence of $P$. periphylla could be the result of patchy distribution or by avoidance behaviour.

Our results provide a first overview of the vertical composition, distribution and abundance of macroplankton in the Norwegian Sea. We show that predatory and, to a lesser degree, filter feeding non-crustacean zooplankton dominate the mesopelagic macroplankton community of the study area. The resultant vertical abundance distributions may be useful for modelling trophic pathways and vertical flux in the mesopelagic. More detailed, net- or ROV-based studies are necessary in order to describe the currently poorly known species level diversity of gelatinous zooplankton in this region. Additionally, the absence of observations of the abundant squid G. fabricii asks for a more intense sampling program to better understand the biology of this important species.

Acknowledgements We thank the captain and crew of RV HEINCKE for their professional support which allowed the collection of the data presented here. Dr. Steven Haddock and an anonymous referee are thanked for reviewing the manuscript, which improved the quality. $\mathrm{HJH}$ is funded by the German Research Foundation (DFG) under grant HO 5569/2-1 (Emmy Noether Junior Research Group).

Author contributions HJH designed the research, HJH and UP applied for funding and organized fieldwork, $\mathrm{HJH}$, UP, AH performed fieldwork, $\mathrm{PN}, \mathrm{HJH}, \mathrm{AH}$ analyzed video transects, $\mathrm{PN}$ analyzed and visualized the data, PN, HJH, AH and UP contributed to writing the paper.

Funding Open Access funding enabled and organized by Projekt DEAL. HJH is funded by the DFG under grant HO 5569/2-1 (Emmy Noether Junior Research Group). Shiptime was provided by the DFG. 
Data availability https://doi.org/10.1594/PANGAEA.927705.

\section{Declarations}

Conflict of interest The authors declare that they have no conflict of interest to disclose.

Open Access This article is licensed under a Creative Commons Attribution 4.0 International License, which permits use, sharing, adaptation, distribution and reproduction in any medium or format, as long as you give appropriate credit to the original author(s) and the source, provide a link to the Creative Commons licence, and indicate if changes were made. The images or other third party material in this article are included in the article's Creative Commons licence, unless indicated otherwise in a credit line to the material. If material is not included in the article's Creative Commons licence and your intended use is not permitted by statutory regulation or exceeds the permitted use, you will need to obtain permission directly from the copyright holder. To view a copy of this licence, visit http://creativecommons.org/licenses/by/4.0/.

\section{References}

Alldredge A (2004) The contribution of discarded appendicularian houses to the flux of particulate organic carbon from oceanic surface waters. In: Gorsky G, Youngbluth MJ, Deibel D (eds) Response of marine ecosystems to global change: Ecological impact of appendicularians. Éditions des Archives Contemporaines, Paris, pp 309-326

Arkhipkin AI, Bjørke H (1999) Ontogenetic changes in morphometric and reproductive indices of the squid Gonatus fabricii (Oegopsida, Gonatidae) in the Norwegian Sea. Polar Biol 22:357-365. https://doi.org/10.1007/s003000050429

Båmstedt U, Kaartvedt S, Youngbluth M (2003) An evaluation of acoustic and video methods to estimate the abundance and vertical distribution of jellyfish. J Plankton Res 25:1307-1318. https:// doi.org/10.1093/plankt/fbg084

Barham EG (1966) Deep scattering layer migration and composition: observations from a diving saucer. Science 151:1399-1403. https://doi.org/10.1126/science.151.3716.1399

Bayha KM, Harbison GR, Mcdonald JH, Gaffney PM (2004) Preliminary investigation on the molecular systematics of the invasive ctenophore Beroe ovata. Aquatic invasions in the Black, Caspian, and Mediterranean Seas. Dumont H. Kluwer Academic Publishers, Dordrecht, pp 167-175

Bergstad OA, Gjelsvik G, Schander C, Høines ÅS (2010) Feeding ecology of Coryphaenoides rupestris from the mid-atlantic ridge. PLoS ONE 5:1-10. https://doi.org/10.1371/journal.pone.0010453

Bjørke H (2001) Predators of the squid Gonatus fabricii (Lichtenstein) in the Norwegian Sea. Fish Res 52:113-120. https://doi.org/10. 1016/S0165-7836(01)00235-1

Blindheim J, Rey F (2004) Water-mass formation and distribution in the Nordic Seas during the 1990s. ICES J Mar Sci 61:846-863. https://doi.org/10.1016/j.icesjms.2004.05.003

Bone Q, Kapp H, Perrot-Bults AC (eds) (1991) The biology of chaetognaths. Oxford University Press, Oxford

Brotz L, Cheung WWL, Kleisner K et al (2012) Increasing jellyfish populations: trends in large marine ecosystems. Hydrobiologia 690:3-20. https://doi.org/10.1007/s10750-012-1039-7

Cardona L, de Quevedo IÁ, Borrell A, Aguilar A (2012) Massive consumption of Gelatinous Plankton by Mediterranean Apex Predators. PLoS ONE 7:1-14. https://doi.org/10.1371/journal.pone. 0031329
Choy CA, Haddock SHD, Robison BH (2017) Deep pelagic food web structure as revealed by in situ feeding observations. Proc R Soc B Biol Sci 284:1-10. https://doi.org/10.1098/rspb.2017.2116

Christiansen S, Hoving HJT, Schütte F et al (2018) Particulate matter flux interception in oceanic mesoscale eddies by the polychaete Poeobius sp. Limnol Oceanogr 63:2093-2109. https://doi.org/10. 1002/lno.10926

Condon RH, Graham WM, Duarte CM et al (2012) Questioning the Rise of Gelatinous Zooplankton in the World's Oceans. Bioscience 62:160-169. https://doi.org/10.1525/bio.2012.62.2.9

Condon RH, Duarte CM, Pitt KA et al (2013) Recurrent jellyfish blooms are a consequence of global oscillations. Proc Natl Acad Sci USA 110:1000-1005. https://doi.org/10.1073/pnas.12109 20110

Dale T, Bagøien E, Melle W, Kaartvedt S (1999) Can predator avoidance explain varying overwintering depth of Calanus in different oceanic water masses? Mar Ecol Prog Ser 179:113-121. https:// doi.org/10.3354/meps 179113

Dalpadado P, Ellertsen B, Melle W, Skjoldal HR (1998) Summer distribution patterns and biomass estimates of macrozooplankton and micronekton in the nordic seas. Sarsia 83:103-116. https:// doi.org/10.1080/00364827.1998.10413676

De La Rocha CL, Passow U (2007) Factors influencing the sinking of POC and the efficiency of the biological carbon pump. Deep Res II 54:639-658. https://doi.org/10.1016/j.dsr2.2007.01.004

Ekau W, Auel H, Pörtner H-O, Gilbert D (2010) Impacts of hypoxia on the structure and processes in pelagic communities (zooplankton, macro-invertebrates and fish). Biogeosciences 7:1669-1699. https://doi.org/10.5194/bg-7-1669-2010

Falkenhaug T (1991) Prey composition and feeding rate of Sagitta elegans var. arctica (chaetognatha) in the Barents Sea in early summer. Polar Res 10:487-506. https://doi.org/10.3402/polar. v10i2.6761

Frank TM, Widder EA (2002) Effects of a decrease in downwelling irradiance on the daytime vertical distribution patterns of zooplankton and micronekton. Mar Biol 140:1181-1193. https:// doi.org/10.1007/s00227-002-0788-7

Granhag L, Majaneva S, Friis Møller L (2012) First recording of the ctenophore Euplokamis sp. (Ctenophora, Cydippida) in Swedish coastal waters and molecular identification of this genus. Aquat Invasions 7:455-463. https://doi.org/10.3391/ai.2012.7.4.002

Haddock SHD (2004) A golden age of gelata: past and future research on planktonic ctenophores and cnidarians. Hydrobiologia 530:549-556. https://doi.org/10.1007/s10750-004-2653-9

Heeger T, Piatkowski U, Möller H (1992) Predation on jellyfish by the cephalopod Argonauta argo. Mar Ecol Prog Ser 88:293296. https://doi.org/10.3354/meps088293

Henschke N, Bowden DA, Everett JD et al (2013) Salp-falls in the Tasman Sea: a major food input to deep-sea benthos. Mar Ecol Prog Ser 491:165-175. https://doi.org/10.3354/meps 10450

Holland LZ (2016) Tunicates. Curr Biol Mag 26:146-152. https:// doi.org/10.1016/j.cub.2015.12.024

Hosia A, Båmstedt U (2007) Seasonal changes in the gelatinous zooplankton community and hydromedusa abundances in Korsfjord and Fanafjord, western Norway. Mar Ecol Prog Ser 351:113127. https://doi.org/10.3354/meps07148

Hosia A, Stemmann L, Youngbluth M (2008) Distribution of netcollected planktonic cnidarians along the northern Mid-Atlantic Ridge and their associations with the main water masses. Deep Res Part II 55:106-118. https://doi.org/10.1016/j.dsr2.2007.09. 007

Hosia A, Falkenhaug T, Baxter EJ, Pagès F (2017) Abundance, distribution and diversity of gelatinous predators along the northern Mid-Atlantic Ridge: a comparison of different sampling methodologies. PLoS ONE 12:1-18. https://doi.org/10.1371/ journal.pone.0187491 
Hoving HJT, Haddock SHD (2017) The giant deep-sea octopus Haliphron atlanticus forages on gelatinous fauna. Sci Rep 7:14. https://doi.org/10.1038/srep44952

Hoving HJT, Neitzel P, Robison B (2018) In situ observations lead to the discovery of the large ctenophore Kiyohimea usagi (Lobata: Eurhamphaeidae) in the eastern tropical Atlantic. Zootaxa 4526:232-238. https://doi.org/10.11646/zootaxa.4526.2.8

Hoving HJT, Christiansen S, Fabrizius E et al (2019) The Pelagic In situ Observation System (PELAGIOS) to reveal biodiversity, behavior, and ecology of elusive oceanic fauna. Ocean Sci 15:1327-1340. https://doi.org/10.5194/os-15-1327-2019

Johansson ML, Shiganova TA, Ringvold H et al (2018) Molecular Insights Into the Ctenophore Genus Beroe in Europe: new species, spreading invaders. J Hered 109:520-529. https://doi.org/ 10.1093/jhered/esy026

Kaartvedt S, Staby A, Aksnes DL (2012) Efficient trawl avoidance by mesopelagic fishes causes large underestimation of their biomass. Mar Ecol Prog Ser 456:1-6. https://doi.org/10.3354/ meps09785

Kristensen TK (1984) Biology of the Squid Gonatus fabricii (Lichtenstein, 1818) from West Greenland Waters. Meddelelser om Gronland. Biosci 13:2-20

Latasa M, Cabello AM, Morán XAG et al (2017) Distribution of phytoplankton groups within the deep chlorophyll maximum. Limnol Oceanogr 62:665-685. https://doi.org/10.1002//no.10452

Lebrato M, Pitt KA, Sweetman AK et al (2012) Jelly-falls historic and recent observations: a review to drive future research directions. Hydrobiologia 690:227-245. https://doi.org/10.1007/ s10750-012-1046-8

Licandro P, Blackett M, Fischer A et al (2015) Biogeography of jellyfish in the North Atlantic, by traditional and genomic methods. Earth Syst Sci Data 7:173-191. https://doi.org/10.5194/ essd-7-173-2015

Lick R, Piatkowski U (1998) Stomach contents of a Norther Bottelnose Whale (Hyperoodon ampullatus) Stranded at Hiddensee, Baltic Sea. J Mar Biol Assoc UK 78:643-650. https://doi.org/10.1017/ S0025315400041679

Linke P, Schmidt M, Rohleder M et al (2015) Novel online digital video and high-speed data broadcasting via standard coaxial cable onboard marine operating vessels. Mar Technol Soc J 49:7-18. https://doi.org/10.4031/MTSJ.49.1.2

Lynam CP, Lilley MKS, Bastian T et al (2011) Have jellyfish in the Irish Sea benefited from climate change and overfishing? Glob Chang Biol 17:767-782. https://doi.org/10.1111/j.1365-2486. 2010.02352.x

Majaneva S, Majaneva M (2013) Cydippid ctenophores in the coastal waters of Svalbard: is it only Mertensia ovum. Polar Biol 36:16811686. https://doi.org/10.1007/s00300-013-1377-6

Matsumoto GI, Robison BH (1992) Kiyohimea usagi, a new species of lobate ctenophore from the Monterey Submarine Canyon. Bull Mar Sci 51:19-29

Melle W, Ellertsen B, Skjoldal HR (2004) Zooplankton: the link to higher trophic levels. In: Skjoldal HR, Saetre R (eds) The Norwegian Sea Ecosystem. Tapir Academic Press, Trondheim, pp 137-202

Mills CE, Haddock SHD (2007) Intertidal invertebrates of the Central California Coast. In: Carlton JT (ed) The light and smith manual. University of California Press, Berkeley

Nagabhushanam AK (1959) Feeding of a Ctenophore, Bolinopsis Infundibulum (O. F. Müller). Nature 184:829. https://doi.org/10. 1038/184829a0

Norheim E, Klevjer TA, Aksnes DL (2016) Evidence for light-controlled migration amplitude of a sound scattering layer in the Norwegian Sea. Mar Ecol Prog Ser 551:45-52. https://doi.org/ $10.3354 /$ meps 11731
Pagès F, Flood P, Youngbluth M (2006) Gelatinous zooplankton netcollected in the Gulf of Maine and adjacent submarine canyons: new species, new family (Jeanbouilloniidae), taxonomic remarks and some parasites. Sci Mar 70:363-379. https://doi.org/10.3989/ scimar.2006.70n3363

Piatkowski U, Rodhouse PG, White MG et al (1994) Nekton community of the Scotia Sea as sampled by the RMT 25 during austral summer. Mar Ecol Prog Ser 112:13-28. https://doi.org/10.3354/ meps 112013

Raymond EH, Widder EA (2007) Behavioral responses of two deepsea fish species to red, far-red, and white light. Mar Ecol Prog Ser 350:291-298. https://doi.org/10.3354/meps07196

Reisenbichler KR, Chaffey MR, Cazenave F et al (2016) Automating MBARI 's midwater time-series video surveys: the transition from ROV to AUV. OCEANS 2016 MTS/IEEE Monterey. IEEE, Monterey, pp 1-9

Robinson C, Steinberg DK, Anderson TR et al (2010) Mesopelagic zone ecology and biogeochemistry-a synthesis. Deep Res Part II 57:1504-1518. https://doi.org/10.1016/j.dsr2.2010.02.018

Robison BH (2004) Deep pelagic biology. J Exp Mar Bio Ecol 300:253-272. https://doi.org/10.1016/j.jembe.2004.01.012

Robison BH, Reisenbichler KR, Sherlock RE (2005) Giant Larvacean houses: rapid carbon transport to the deep sea floor. Science 308:1609-1611. https://doi.org/10.1126/science.1109104

Robison BH, Reisenbichler KR, Sherlock RE (2017) The coevolution of midwater research and ROV technology at MBARI. Oceanography 30:26-37. https://doi.org/10.5670/oceanog.2017.421

Santos MB, Pierce GJ, Boyle PR et al (1999) Stomach contents of sperm whales Physeter macrocephalus stranded in the North Sea 1990-1996. Mar Ecol Prog Ser 183:281-294. https://doi.org/10. 3354/meps 183281

Satterlie RA, LaBarbera M, Spencer AN (1985) Swimming in the Pteropod Mollusc, Clione Limacina. J Exp Biol 116:189-205

Schlining BM, Jacobsen Stout N (2006) MBARI's video annotation and reference system. OCEANS 2006. IEEE, Boston, pp 1-5

Stemmann L, Hosia A, Youngbluth MJ et al (2008) Vertical distribution $(0-1000 \mathrm{~m})$ of macrozooplankton, estimated using the Underwater Video Profiler, in different hydrographic regimes along the northern portion of the Mid-Atlantic Ridge. Deep Res Part II 55:94-105. https://doi.org/10.1016/j.dsr2.2007.09.019

Stoner AW, Ryer CH, Parker SJ et al (2008) Evaluating the role of fish behavior in surveys conducted with underwater vehicles. Can J Fish Aquat Sci 65:1230-1243. https://doi.org/10.1139/F08-032

Sweetman AK, Chapman A (2015) First assessment of flux rates of jellyfish carcasses (jelly-falls) to the benthos reveals the importance of gelatinous material for biological C-cycling in jellyfishdominated ecosystems. Front Mar Sci 2:1-7. https://doi.org/10. 3389/fmars.2015.00047

Thuesen EV, Rutherford LD, Brommer PL et al (2005) Intragel oxygen promotes hypoxia tolerance of scyphomedusae. J Exp Biol 208:2475-2482. https://doi.org/10.1242/jeb.01655

Utne-Palm AC, Breen M, Løkkeborg S, Humborstad O-B (2018) Behavioural responses of krill and cod to artificial light in laboratory experiments. PLoS ONE 13:1-17. https://doi.org/10.1371/ journal.pone.0190918January

Vecchione M, Young RE, Piatkowski U (2010) Cephalopods of the northern Mid-Atlantic Ridge. Mar Biol Res 6:25-52. https://doi. org/10.1080/17451000902810751

Vinogradov GM (2005) Vertical distribution of macroplankton at the Charlie-Gibbs Fracture Zone (North Atlantic), as observed from the manned submersible "Mir-1." Mar Biol 146:325-331. https:// doi.org/10.1007/s00227-004-1436-1

Wiborg KF, Gjøsæter J, Beck IM (1984) The Squid Gonatus fabricii (Lichtenstein) Investigations the Norwegian Sea and Western Barents Sea 1982-1983. ICES C Doc. pp 1-14 
Wiebe PH, Ashjian CJ, Gallager SM et al (2004) Using a high-powered strobe light to increase the catch of Antarctic krill. Mar Biol 144:493-502. https://doi.org/10.1007/s00227-003-1228-z

Publisher's Note Springer Nature remains neutral with regard to jurisdictional claims in published maps and institutional affiliations. 